\title{
KEUNGGULAN RELATIF KAMBING PERSILANGAN BOER DAN KACANG
}

\author{
Ratna Kumala Dewi ${ }^{1)}$ dan Wardoyo ${ }^{2)}$ \\ 1) Program Studi Peternakan Fakultas Peternakan Universitas Islam Lamongan \\ 2) Fakultas Peternakan Universitas Islam Lamongan. \\ JI.Veteran No.53.A Lamongan
}

\begin{abstract}
ABSTRAK
Persilangan adalah salah satu metode peningkatan mutu genetik ternak untuk meningkatkan produktivitas ternak dalam waktu relatif singkat. Kambing Boer dipilih untuk meningkatkan produktifitas kambing Kacang karena kambing jenis ini memiliki proporsi badan yang bagus dan mudah beradaptasi dengan berbagai kondisi lingkungan. Penelitian ini bertujuan untuk mengevaluasi potensi genetik pejantan Boer berdasarkan performa hasil persilangannya dengan kambing Kacang di UPT Agriscience Technopark UNISLA. Materi yang digunakan adalah 8 jantan dan 11 betina kambing persilangan Boer dengan kambing Kacang. Variabel yang digunakan adalah bobot lahir dan bobot sapih. Data bobot lahir (BL) dan bobot sapih (BS) dianalisa dengan analisis ANOVA. Perbedaan mean dianalisa dengan Duncant Multiple Range Test. Bobot Lahir (BL) dari persilangan kambing Boer dan Kacang adalah 2,525 $\pm 0,91 \mathrm{~kg}$ untuk jantan dan 2,16 $\pm 0,56 \mathrm{~kg}$ untuk betina. Bobot Sapih (BS) adalah 10,67 \pm 4,57 kg untuk jantan dan 8,36 $\pm 2,34 \mathrm{~kg}$ untuk betina
\end{abstract}

Kata Kunci: Persilangan, Pejantan Boer, Kambing Kacang, Performa

\section{PENDAHULUAN}

Kambing merupakan salah satu jenis ternak ruminansia yang potensial dikembangkan sebagai ternak penghasil daging dalam rangka pemenuhan kebutuhan daging nasional yang terus meningkat. Peningkatan produktivitas ternak dapat dilakukan melalui dua cara, yaitu dengan melakukan perbaikan lingkungan (mutu pakan dan tatalaksana) serta dengan menggunakan program pemuliaan. Peningkatan mutu genetik melalui program pemuliaan dapat dilakukan dengan dua cara yaitu dengan melakukan persilangan dan dengan program seleksi. Persilangan merupakan suatu cara untuk memperoleh individu-individu yang memiliki sejumlah sifat unggul yang dimiliki oleh kedua bangsa tetuanya.

Kambing Boer adalah salah satu jenis kambing unggul penghasil daging yang didatangkan ke Indonesia. Keunggulan genetik yang dimiliki Kambing Boer adalah pertumbuhan cepat, mudah beradaptasi pada berbagai kondisi lingkungan, mempunyai kualitas daging yang bagus sesuai dengan konformasi tubuhnya, serta mempunyai sifat reproduksi yang baik (Van Niekerk dan Casey, 1988). Menurut Ted dan Shipley (2005) kambing Boer jantan dewasa berumur 2-3 tahun dapat mencapai bobot antara $110-135 \mathrm{~kg}$ dan kambing Boer betina dewasa antara 90-100 kg. Dengan laju pertambahan bobot badan harian berkisar antara 203-204 g (Erasmus, 2000), persilangan Kambing Boer galur murni (pure breed) dengan kambing lokal diharapkan mampu meningkatkan produktivitas kambing lokal. Peningkatan mutu hasil persilangan akan dapat dicapai dengan adanya aplikasi program pemuliaan yang terarah dan berkesinambungan.

Di Kabupaten Lamongan, persilangan kambing Kacang dengan Kambing Boer masih merupakan hal baru dan belum banyak diaplikasikan ke masyarakat peternak. Sebagian besar kambing yang diternakkan adalah kambing Kacang lokal dan Peranakan Etawah (PE). Dengan adanya introduksi kambing Boer dan melakukan program persilangan dengan kambing lokal diharapkan dapat meningkatkan mutu genetik kambing lokal.

Berdasarkan kenyataan di lapang tersebut maka evaluasi pejantan Boer yang digunakan dalam program persilangan sangat perlu dilakukan agar dapat dihasilkan hasil persilangan yang unggul. Potensi genetic dapat tercermin dari beberapa sifat produksi, diantaranya adalah bobot lahir, bobot sapih, dan pertambahan bobot badan harian sebelum sapih.

\section{MATERI DAN METODE}

Penelitian dilaksanakan di Unit Pelaksana Teknis (UPT) Agriscience Technopark Universitas Islam Lamongan. Materi yang digunakan dalam penelitian ini adalah kambing keturunan pertama (F1) hasil persilangan pejantan Boer murni dengan kambing Kacang sebanyak 8 jantan dan 11 betina.

Metode yang digunakan dalam penelitian ini adalah pengamatan langsung di kandang UPT Agriscience Technopark UNISLA dengan sampel sejumlah 19 ekor kambing hasil persilangan F1 
yang telah mencapai umur sapih dan mempunyai catatan lahir.

Data bobot sapih dikoreksi ke dalam bobot sapih umur 90 hari. Rumus yang digunakan untuk mengoreksi bobot sapih ke dalam bobot sapih umur 90 hari menurut Hardjosubroto (1994) adalah sebagai berikut:

$$
B S(90 \text { hari })=B L+\frac{B S D-B L}{U S D} \times 90
$$

Keterangan : $\mathrm{BL}=$ Bobot Lahir

BS = Bobot Sapih

BSD = Bobot Saat Ditimbang

USD = Umur Saat Ditimbang

Variabel yang diamati dalam penelitian ini adalah: Bobot lahir, Bobot sapih (bobot badan umur 90 hari). Data dianalisis dengan ANOVA (Analysis of Varians) dengan software GENSTAT. Model statistiknya adalah sebagai berikut:

$$
Y i j=\mu+\alpha i+e i j
$$

Dimana, $Y i j=$ nilai pengamatan pada anak ke-j dari pejantan ke-i

$\mu=$ nilai rataan

$\alpha i=$ pengaruh pejantan ke-i

e $i j=$ pengaruh lingkungan yang tidak terkontrol dan penyimpangan genetik dari individu

\section{HASIL DAN PEMBAHASAN \\ Bobot Lahir Kambing Hasil Persilangan Pertama (F1) Pejantan Boer dengan Kambing Lokal}

Rataan bobot lahir kambing hasil persilangan pertama (F1) pejantan Boer dengan kambing Kacang lokal disajikan pada Tabel 1.

Tabel 1. Rataan bobot lahir (BL) dan koefisien keragaman (KK) kambing hasil persilangan ( $\mathrm{F} 1)$ pejantan

\begin{tabular}{|c|c|c|c|}
\hline Bobot Lahir & Jumlah Anak & Rata-Rata BL (kg) & KK (\%) \\
\hline BL Jantan & 8 & $2,525 \pm 0,91^{a}$ & 36,04 \\
\hline BL Betina & 11 & $2,16 \pm 0,56^{b}$ & 25,88 \\
\hline
\end{tabular}
Boer murni dengan kambing lokal Kacang

Huruf yang berbeda pada kolom yang sama menunjukkan perbedaan yang sangat nyata $(P<0,05)$

Berdasarkan hasil analisis keragaman dapat dilihat bahwa bobot lahir kambing jantan hasil persilangan berbeda sangat nyata dengan bobot lahir betina, dimana rataan bobot lahir jantan $(2,525 \pm 0,91 \mathrm{~kg})$ lebih tinggi daripada rataan bobot lahir betina $(2,16 \pm 0,56 \mathrm{~kg})$. Hal ini sesuai dengan Devendra dan Burns (1994) yang menyatakan bahwa anak jantan lebih berat daripada anak betina pada bangsa kambing yang sama dan kategori kelahiran yang sama (kelahiran tunggal ataupun kelahiran ganda). Bobot lahir jantan lebih besar daripada betina diakibatkan oleh hormon androgen yang dimiliki oleh anak jantan akan menyebabkan adanya retensi nitrogen lebih banyak dibandingkan dengan anak betina, sehingga akan mengakibatkan pertumbuhan anak jantan yang lebih besar (Ihsan, 1990). Sedangkan menurut Kostaman dan Sutama (2005) hal tersebut terjadi karena pertumbuhan pra lahir kambing anak jantan lebih cepat bila dibandingkan dengan betina. Perbedaan bobot lahir antara jantan dan betina pada penelitian ini adalah sebesar 0,365 $\mathrm{kg}(14,45 \%)$, lebih tinggi dari penelitian Mahmilia dan Doloksaribu (2010) sebesar 9,72\%
Rataan bobot lahir yang didapat dari penelitian ini lebih besar jika dibandingkan dengan bobot lahir kambing lokal. Bobot lahir kambing Kacang menurut Elieser dkk (2007) dan Mahmilia (2010) masing-masing adalah sebesar $1,4 \mathrm{~kg}$ dan $1,69 \mathrm{~kg}$. Peningkatan bobot lahir ini diduga disebabkan oleh adanya efek heterosis dari program persilangan antara pejantan unggul Boer murni dengan kambing lokal. Mahmalia dan Tarigan (2007) menyatakan bahwa persilangan antara kambing Boer dengan kambing lokal akan memberikan dampak positif diantaranya adalah peningkatan bobot lahir keturunannya. Besaran bobot lahir suatu ras kambing sangat ditentukan oleh konformasi serta besaran ukuran tubuh tetuanya (Morand-Fehr, 1981), dalam hal ini faktor pejantan (kambing Boer) yang digunakan serta kemurniaan genotipenya. Kambing Boer adalah kambing yang mempunyai potensi genetik tinggi dan tipe pedaging yang baik karena mempunyai konfirmasi tubuh dengan tulang rusuk yang lentur, panjang badan dan perototan yang baik pula. Disamping itu besar kambing lokal (induk) yang dikawinkan serta ransum pakan yang dikonsumsi juga menentukan besarnya tubuh dan kecepatan 
pertumbuhan anak yang dilahirkan (Ted dan Shipley, 2005).

Rataan bobot lahir dari hasil penelitian ini juga menunjukkan bobot yang lebih tinggi daripada hasil penelitian Mahmilia dan Doloksaribu (2010) pada kambing Boer yang disilangkan dengan kambing Kacang yaitu sebesar 2,16 \pm 0,54 kg untuk jantan dan 1,95 \pm $0,56 \mathrm{~kg}$ untuk betina. Sedangkan berdasarkan hasil penelitian Nurgiartiningsih (2011) menunjukkan bobot lahir sedikit lebih tinggi yaitu $2,538 \pm 0,48 \mathrm{~kg}$ untuk jantan dan $2,187 \pm 0,56 \mathrm{~kg}$ untuk betina.

Bobot Sapih Kambing Hasil Persilangan
Pejantan Boer dengan Kambing Lokal Kacang
Rataan bobot sapih kambing hasil persilangan
(F1) pejantan Boer dengan kambing lokal
Kacang disajikan pada Tabel 2 berikut:

Tabel 2. Rataan bobot sapih (BS) dan koefisien keragaman (KK) kambing hasil persilangan (F1) pejantan Boer murni dengan kambing lokal Kacang.

\begin{tabular}{cccc}
\hline Bobot Lahir & Jumlah Anak & Rata-Rata BL $(\mathrm{kg})$ & KK $(\%)$ \\
\hline BS Jantan & 8 & $10,67 \pm 4,57^{\mathrm{a}}$ & 42,84 \\
BS Betina & 11 & $8,36 \pm 2,34^{\mathrm{b}}$ & 27,98 \\
\hline
\end{tabular}

Huruf yang berbeda pada kolom yang sama menunjukkan perbedaan yang sangat nyata $(P<0,05)$

Bobot sapih sangat erat kaitannya dengan bobot lahir. Semakin tinggi bobot lahir maka bobot sapih juga akan semakin berat (Pitono et al., 1992). Lebih lanjut dikatakan bahwa sistem perkawinan silang dapat memberi peluang untuk mempercepat perbaikan produksi. Dari data 19 sampel yang dianalisis dan dikelompokkan berdasarkan jenis kelamin diketahui bahwa perbedaan jenis kelamin berpengaruh nyata terhadap bobot sapih, dimana bobot sapih jantan $(10,67 \pm 4,57 \mathrm{~kg})$ lebih berat daripada betina $(8,36 \pm 2,34 \mathrm{~kg})$ dengan perbedaan sebesar $2,31 \mathrm{~kg}(21,65 \%)$. Hal ini berhubungan dengan adanya persaingan dalam memperoleh makanan, dimana jantan lebih agresif daripada betina khususnya pada saat menyusui. Setiadi et al (2001) juga mendapatkan bobot sapih anak jantan lebih berat 11,93\% dibandingkan dengan betina.

Rataan bobot sapih hasil penelitian lebih rendah dibanding bobot sapih kambing Boer, dimana menurut Barry dan Godke (1997) sebesar 19,4 kg dan menurut Lu (2002) bobot badan kambing Boer pada saat disapih dapat mencapai $20-25 \mathrm{~kg}$. Namun jika dibandingkan dengan kambing Kacang dengan bobot sapih $5,87 \mathrm{~kg}$ (Mahmilia dan Doloksaribu, 2010) dan bobot sapih kambing PE 8,6-10,1 kg (Subandriyo, 2007), maka bobot sapih hasil persilangan tampak lebih besar. Peningkatan bobot sapih ini disebabkan oleh adanya efek heterosis, dimana hasil persilangan menampilkanperformans yang lebih ungguldibandingkan dengan rataan kedua tetuanya.

Rataan bobot sapih kambing hasil persilangan pada penelitian ini $(9,515 \mathrm{~kg})$ lebih rendah dibandingkan penelitian Nurgiartiningsih (2011) yaitu sebesar $11,2 \mathrm{~kg}$ dan Setiadi et al (2001) sebesar $13,02 \mathrm{~kg}$. Namun nilai tersebut masih lebih tinggi bila dibandingkan dengan hasil persilangan kambing Boer dengan kambing Kacang penelitian Romjali, dkk (2000) yang dikutip Sutama (2005) yaitu sebesar $7,69 \mathrm{~kg}$. Perbedaan bobot sapih tersebut mungkin disebabkan oleh perbedaan manajemen terutama aspek pemberian pakan induk saat menyusui, dimana kualitas dan kuantitas pakan yang diberikan akan mempengaruhi produksi susu induk dan secara langsung akan mempengaruhi pertumbuhan anak sebelum disapih sehingga akan berpengaruh terhadap bobot sapih.

\section{Evaluasi Genetik Hasil Persilangan Pejantan Boer dan Kambing Kacang}

Evaluasi potensi genetik pejantan merupakan salah satu program pemuliaan yang sangat penting dalam seleksi ternak. Seleksi berdasarkan potensi genetik akan mampu meningkatkan efektivitas seleksi sehingga dapat meningkatkan kemajuan genetik akibat seleksi. Potensi genetik pejantan dapat tercermin dari kualitas keturunannya yang dapat diprediksi dari performans yang dapat diukur. Bobot lahir dan bobot sapih merupakan dua variabel penting dalam menduga kemampuan berproduksi individu ternak.

Hardjosubroto (1994) menyatakan bahwa uji keturunan dilakukan untuk menilai kemampuan genetik pejantan dengan menduga performans keturunannya. 
Tabel 3. Keunggulan Relatif Kambing Hasil Persilangan (F1) Boer X Kacang pada Periode Prasapih terhadap Kambing Kacang

\begin{tabular}{lccc}
\hline Parameter Pertumbuhan & Kacang $^{\mathrm{a})}$ & ${\text { Boer } \times \text { Kacang }^{\mathrm{b})}}$ & $\begin{array}{c}\text { Persentase } \\
\text { Keunggulan } \\
\text { Relatif }\end{array}$ \\
\hline Rataan BL $(\mathrm{kg})$ & 1,69 & 2,34 & $27,78 \%$ \\
Rataan BS $(\mathrm{kg})$ & 5,87 & 9,515 & $38,31 \%$ \\
Rataan PBHH $(\mathrm{g})$ & 45,67 & 77,97 & $41,43 \%$ \\
\hline
\end{tabular}

a) Mahmilia dan Doloksaribu (2010)

b) Data Primer Diolah (2018)

Dapat dilihat pada Tabel 3 bahwa rataan bobot lahir, bobot sapih dan pertambahan bobot badan harian pra sapih pada kambing persilangan pada penelitian ini lebih tinggi daripada kambing Kacang (Mahmilia dan Doloksaribu, 2010). Persentase perbedaan antara kambing persilangan dengan Kacang untuk bobot lahir mencapai $27,78 \%$, bobot sapih $38,31 \%$ dan pertambahan bobot badan harian mencapai persentase tertinggi yaitu $41,43 \%$. Penggunaan pejantan Boer, ras kambing tipe besar merupakan kontributor utama terhadap tingginya laju pertumbuhan kambing persilangan F1. Kambing Boer termasuk tipe pedaging dengan laju pertumbuhan tinggi yang dapat mencapai $250 \mathrm{~g} / \mathrm{hari}$, tergantung pada pakan yang dikonsumsi (Barry dan Godke, 1991). Dengan perkataan lain laju pertumbuhan kambing Boerka lebih cepat daripada laju pertumbuhan kambing Kacang.

Namun laju pertumbuhan Boerka pada pengamatan ini lebih rendah dibandingkan dengan laju pertumbuhan kambing silangan Boer x Spanish sebesar $100 \mathrm{~g} / \mathrm{h}$ (Prieto et al.,2000) maupun Boer x Anggora sebesar $161 \mathrm{~g}$ hari-1 (Cameron et al., 1999) pada umur 4 - 8 bulan. Hal ini terkait dengan kapasitas ukuran tubuh dewasa kambing Kacang yang lebih rendah dibandingkan dengan Spanish dan Anggora.

\section{KESIMPULAN}

Berdasarkan hasil penelitian yang telah dilakukan dapat diambil beberapa kesimpulan yaitu, (1) Bobot lahir dan bobot sapih keturunan hasil persilangan Boer dengan kambing lokal jenis kelamin jantan lebih besar daripada betina, (2) kambing persilangan memiliki bobot lahir dan bobot sapih yang lebih berat daripada kambing Kacang, (3) keunggulan relatif berkisar 27,78\% untuk bobot lahir, 38,31\% untuk bobot sapih dan $41,43 \%$ untuk pertambahan bobot hidup harian prasapih.

\section{DAFTAR PUSTAKA}

Barry, D.D. and R.A Godke. 1991. The Boer goat: The potensial for crossbreeding. Proceedings of the National symposium on goat meat production and marketing. August 16-18, 1991, Tulsa, Oklahoma. Langston university, Langson, OK, USA. pp. 180-189.

Cameron, M.R., J. Luo, T. Sahlu, S.P. Hart, S.W. Cole and A.L. Goetsch. 2001. Growth and slaughter traits of Boer $x$ Spanish, Boer $x$ Angora and Spanish goats consuming a concentrate-based diet. J. Anim. Sci. 79: 1423-1430.

Devendra, C. and G.B. McLeroy. 1982. Goat and Sheep Production in the Tropic. Toppan Printing. Co. (S). Pte. Ltd. Singapore.

Elieser, S., M. Doloksaribu, F.Mahmilia, A. Tarigan dan E.Romjali. 2007. Loka Karya Nasional Kambing Potong: Bobot Lahir Beberapa Genotipe Kambing Hasil Persilangan. Loka penelitian kambing potong. Sei Putih. http://peternakan.litbang.deptan.go.id

Erasmus. J.A. 2000. Adaptation to various environments and resistance to disease of improved Boer goat. Small Rumi. Res. 36: 179-187.

Hardjosubroto, W. 1994. Aplikasi Pemuliabiakan Ternak di Lapangan. PT Gramedia Widiasarana Indonesia. Jakarta.

Kostaman, T., dan I.K. Sutama. 2005. Laju pertumbuhan kambing anak hasil persilangan antara kambing boer dengan PE pada periode prasapih. Balai Penelitian Ternak.Bogor. Jurnal IImu Ternak dan Veteriner. Vol $10: 2$

Lu, C.D. 2002. Boer Goat Production: Progress and Perspective. Vice Chancellor of Academic Affairs, University of Hawai'i. Hilo,

Hawai. http://www.uhh.hawaii.edu/uhh/vcaa/

Mahmilia, F., dan A. Tarigan. 2007. Lokakarya Nasional Kambing Potong: Karakteristik Morfologidan Performans Kambing 
Kacang, Kambing Boer, dan Persilangannya. Loka Penelitian Kambing Potong. Sei

Putih.http://peternakan.litbang.deptan.go.id

Mahmilia, Fera dan M. Doloksaribu. 2010. Keunggulan Relatif Anak Hasil Persilangan antara Kambing Boer dengan Kacang pada Periode Prasapih. JITV Vol. 15 No. 2 Th. 2010: 124-130.

Morand-Fehr. 1981. Growth. In: Goat Production. GALL, C. (Ed.). Academis Press, London. Pp. 253-283.

Nurgiartiningsih. 2011. Evaluasi Genetik Pejantan Boer Berdasarkan Performans Hasil Persilangannya dengan Kambing Lokal. Jurnal Ternak Tropika Vol. 12, No.1: 82-88.

Pitono, A.D., E. Romjali dan R.M. Gatenby. 1992. Jumlah anak lahir dan bobot lahir domba lokal Sumatera dan hasil persilangannya. JPP Sungei Putih. 1: 13-19.

Prieto, I., A.L. Goetsch, V. Banskalieva, M. Cameron, R.Puchala, T. Sahlu, L.J. Dawson and S.W. Coleman. 2000. Effects of dietary protein concentration on postweaning growth of Boer crossbred and Spanish goat wethers. J. Anim. Sci. 78: 2275-2281.

Setiadi, B., Subandriyo, M. Martawidjaja, D. Priyanto, D. Yulisstiani, T. Sartika, B.
Tiesnamurti, K. Diwyanto \& L. Praharani. 2001. Evaluasi peningkatan produktivitas kambing persilangan. Kumpulan Hasil Penelitian Peternakan APBN Tahun Anggaran 1999/2000. Buku I. Penelitian Ternak Ruminansia Kecil. Balai Penelitian Ternak, Pusat Penelitian dan Pengembangan Pertanian. Bogor. 157178.

Subandriyo. 2007. Lokakarya Nasional Kambing Potong: Strategi Pemanfaatan Plasma Nutfah Kambing Lokal dan Peningkatan Mutu Genetik Kambing di Indonesia. Balai Penelitian Ternak Bogor.

Sutama, I. K. 2005. Lokakarya Nasional Kambing Potong: Tantangan dan Peluang Peningkatan Produktivitas Kambing melalui Inovasi Technologi Reproduksi. Balai Penelitian Ternak Bogor.

Ted, Shipley and L. Shipley. 2005. Why you should raise Boer goats "Meat for the future". Indonesiaboergoat.com.

Van Niekerk, W.A., and N. H. Casey. 1988. The Boer Goat II. Growth, nutritient requirements, carcass and meat quality. Departement of Livestock Science, Faculty of Agriculture, University of Pretoria. South Africa. Rumin. Res 